\title{
Augusta Faro em Tradução: Scrap Heap
}

\author{
Alison Entrekin
}

\section{SCRAP HeAP}

I could see the full extent of the room from where I had been placed on the shelf. At this angle, I began in complete innocence to observe the derangement of the clothes on their hangers, still smelling of their owner; the books scattered across the desk in resigned waiting, the jumble of shoes under the bed. The silence was long and sharp. It slid down the walls, ran across the floor, rose again and wolfed down the objects in the room. The body of the silence surprised the reposing things. And there I sat, quietly watching that profusion of odours of absent people. They were all out and about, trying to shake off the loneliness that clung to their souls.

In the darkness, I made out shadows and semi-shadows at my feet. The silence was broken by one of Strauss' waltzes flying from the sitting room, an orgy in that desert. Someone had left the radio on. I'd been in the same place for days, almost inert, drowsy even, as drowsy as the absences in that house. I was getting used to the new landscape. I wished I had something to do as I felt anxious in that atmosphere, churned up inside. Boredom weighed at my neck and snagged on my torso. 
I don't know how long it was before I saw him. An old man coming into the room. His face bore the expression of one who had lost his footing and drowned - a look of deep anguish. The fruit in the fruit bowl was motionless, the objects in the room were oblivious. He held an enormous kitchen knife. Glinting steel. He looked at me with avid eyes and the afternoon outside was like feelings devoid of speech. He came over to my side, I saw clearly. In a deranged fury, he pulled my hair out mercilessly, removed my heart and tossed it over by the wardrobe. With dirty fingers, he plucked my eyes out one at a time. Their liquid drained away, but even so I saw the room and the enraged man from other angles. He didn't stop upon tearing my eyes out. He made a gash in my leg with the tip of his knife, peeling back the rubber, pulling out my plastic muscles and breaking my polyethylene bones. I was disfigured. In a carnivorous gesture, he slit open my abdomen and ripped out my guts, separating them as if preparing a dinner party. My blood ran red. With one of my eyes near the man and the other by the bed, we saw different sides of his misalignment and rage, each eye from a different angle.

Fear gripped me; I've never been good at fear management. And the man continued dismembering me. He opened my mouth, peeling back the skin of my face and needling the flesh of my cheeks with the tip of his knife, as if to depetal me. There was nothing I could do, any effort to get away from the brute would have been useless.

He wanted to see inside me, so he separated my torso from my members piece by piece. Last of all, he opened my skull, removed the sphere of my brain and stood there staring at it as if it were a fried egg on a plate, in a mixture of hunger and curiosity. He separated the hemispheres, leaving one on the desk and placing the other by his side. A listlessness took possession of all of my parts. And my eyes remained where they had fallen on the floor, askew but always open, watching that human animal and his knife 
and his strength. Just then two male nurses in white came in and seized the man. He howled like a sick dog. They gave him an injection and his huge, wretched body went limp as like chewing gum. He did not protest as they took him away. My parts lay strewn about and the previous silence returned, immersing shapes and shadows in darkness. Shortly afterwards the young man arrived and went to the phone. He spoke with his mother, I heard clearly. From the things he said, I realized he was telling her about an escapee from a psychiatric clinic, the madman who had laid me waste.

It all began when I came from Yale University in a box, via airmail. The members of the household examined me, showed me to their visitors, and the young man took me to university for his classmates and professors to touch and take apart. Until then I had not felt the loneliness of isolation. But then he stuck me on a shelf and rarely took me down again.

Of technological newfangledness I was made, a reproduction of the human body for science. All of my inner parts precise, wellturned, coloured and full of humours. The battery in the box by my side filled me with vibrations and I know they admired me; they admired themselves greatly for having contrived such an exact copy of the human design.

But I doubt that they can put me back together again, recover my flesh, stitch up my flayed tissues and assemble my broken bones. They have already tried; I lay exposed under a light, many voices putting in their two cents' worth. I know exactly what will happen; one of these days they are going to throw me on the scrap heap. Nothing more. 
ENTREKIN, Alison. Augusta Faro em Tradução: Scrap Heap

\section{Saco de Lixo - Augusta Faro}

Do ângulo em que eu estava, conseguia ver o quarto em toda sua extensão. Colocada ali na prateleira, comecei com minha inocência intocada a observar o desalinho das roupas, ainda com cheiro do dono, dependuradas no cabide; os livros espalhados na escrivaninha numa espera acomodada, os sapatos desencontrados sob a cama. O silêncio era longo e pontudo. Descia das paredes, escorregava pelo assoalho, subia de novo, abocanhava os objetos do quarto. Aliás, o corpo do silêncio surpreendia o descanso das coisas. E eu ali calada, olhando aquela profusão de odores de pessoas ausentes. Aquele povo estava pra rua, às vezes tentando se retirasse deles a solidão grudante em suas almas.

Apagadas as luzes, distingo aos meus pés sombras e semisombras. Devo dizer, o silêncio era repartido por uma valsa de Strauss, que voava da sala, uma orgia naquele deserto - esqueceram o rádio ligado. Havia dias que permanecia no mesmo lugar, quase inerte, até estive sonolenta, tanto quanto as ausências daquela casa. Estava acostumando-me com a nova paisagem. Desejava estar fazendo alguma coisa porque, aflita dentro daquele ar, me sentia com um rebuliço por dentro. $\bigcirc$ tédio pesava no meu pescoço e enganchava no tronco do corpo.

Não sei quanto tempo levou, quando o vi. Era um velho entrando no quarto. No rosto dele a expressão das pessoas que perderam o pé e acabaram sendo afogadas - um olhar de sofrida aflição. Nem as frutas na fruteira se moveram, nem os objetos do quarto perceberam. E ele tinha na mão enorme faca de cozinha. Brilhava comprida. Olhou pra mim com os olhos ávidos, e a tarde lá fora parecia com os sentimentos sem fala. Avançou pro meu lado, vi bem. Com fúria e descontrole me puxou os cabelos sem 
dó, retirou o coração, jogando-o ao lado do guarda-roupas. Com dedos sujos tirou olho por olho. $\bigcirc$ líquido vazou, mesmo assim consegui olhar de outros ângulos o aposento e aquele homem enraivado. Não parou aí, no arrancamento dos olhos. Com a ponta da faca furou minha perna, descolando a borracha, puxando músculos de plástico e quebrando os ossos de polietileno. Eu estava desfigurada. Num gesto de quem gosta de carne, abriu o abdômen, arrancando minhas vísceras, partiu-as como se preparasse um jantar de visitas. $O$ sangue saiu vermelho. Cada olho meu via em perspectivas diferentes, pois o que estava perto do homem, e o outro próximo da cama, víamos cada qual um lado do desalinho do homem e sua braveza.

Sentia o medo me cutucando, meu controle de medo nunca foi bom. E o homem continuava a me destroncar. Abriu minha boca, descolando a pele do rosto e com a ponta da faca alfinetava toda a carne da face, como se fosse me despetalar. Não havia nada que eu pudesse fazer, também de pouco valeriam meus esforços para me safar do brutamonte.

Ele estava a fim de me ver por dentro e por isto, partindo em pedaços, separou meu tronco dos membros. Por fim abriu a caixa craniana, retirou a esfera do cérebro, ficou a olhá-la como se fosse um ovo frito num prato, com um misto de fome e alguma curiosidade. Dividiu os hemisférios, deixando um sobre a escrivaninha e o outro colocou ao seu lado. Um torpor apoderou-se de minhas peças todas. E meus olhos continuavam jogados a um canto, cada qual de um jeito, mas sempre abertos olhando aquele animal humano e sua faca e sua força. Nesse momento entraram dois enfermeiros vestidos de branco e seguraram o homem. Ele berrou como cachorro doente. Deram-lhe uma injeção e o corpo grande desventurado foi ficando mole, fez-se goma de mascar. Levaram-no sem que ele protestasse. Minhas peças todas espalhadas, e o silêncio de antes voltou, mergulhando na penumbra as figuras e suas sombras. Pouco depois chegou o rapaz e foi 
ao telefone. Conversou com a mãe, ouvi bem. Pelo teor do diálogo percebi, contava sobre o insano fugitivo de uma clínica psiquiátrica, aquele que me dilapidou.

Tudo começou quando vim da Universidade de Yale numa caixa, via aérea. Os da casa me examinaram, mostraram às visitas, o rapaz me levou à faculdade para os colegas e professores me tocar e desmontar. Até então não sentia a solidão do isolamento. Mas depois me colocou na prateleira e pouquíssimas vezes me retirava dali.

Na modernice tecnológica me fizeram, reproduzindo o corpo humano para estudos. Todas as peças por dentro certinhas, bem torneadas, coloridas e cheias de humores. A pilha na caixa do lado me enchia de vibrações e, sei muito bem, que me admiravam, tanto se admiravam por terem tramado uma cópia tão exata do feitio humano.

Mas duvido que agora consigam colar minhas partes, recobrir as carnes, arrematar o despelamento dos tecidos e juntar os ossos partidos. Já tentaram, fiquei exposta sob a luz, muitas vozes dando palpites. Sei muito bem, mais dia menos dia, eles vão me jogar fora, num grande saco de lixo. Nada além. 